\section{建築生産関連科目の教育項目の 選択傾向}

高専及び大学の建築生産教育に関する 調査研究 その2

\section{PREFERENCE OF EDUCATIONAL HEADINGS IN LECTURE TYPES OF BUILDING PRODUCTION}

Education of Building Production in Technical Colleges and Universities Part 2

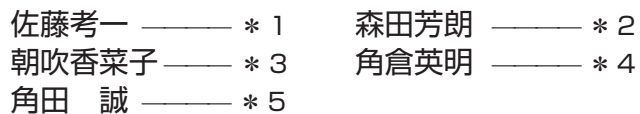

キーワード :

建築生産，建築教育，建築士法，建築再生，アンケート

Keywords:

Building production, Architectural education, Act on architects and building engineers, Renovation, Questionnaire

\section{1. 研究の目的}

前報では ${ }^{1)}$ 、建築生産関連科目の代表的な教科書類に関する調查に 基づき、教育内容を七つの視点と 25 個の教育項目（内訳 93 項目）に 整理した注1)。また全国の大学等の講義担当者に対するアンケート調査 を行い注 2)、建築生産関連科目に関する講義を視点 4（工事の実施）と 視点 5 (建築の利用) の講義回数から三つの類型に整理した注3)。本報 では、教示の程度に関するアンケート回答に基づき注 4$) 、 25$ の教育項 目の選択傾向を講義類型ごとに明らかにする。

\section{2. 講義類型の概要}

建築生産関連科目の三つの講義類型の概要と講義回数の配分の違 いを表 1 と図 1 に示す。類型 $\mathrm{I}$ はいわゆる施工の講義であり注 5 )、「工 事の実施（視点 4$) 」$ 以外の大半は、講義回数が 1 回以下に止まる。 但し視点 $2 、 3$ に 回前後（「(1 回超) 〜 3 回」）の講義回数を割いて

\section{Kouichi SATO \\ Kanako ASABUKI- \\ Makoto TSUNODA}

This paper is one of educational report series to facilitate richer education of building production in technical colleges and universities. The followings are shown by comparing three lecture types classified in last report: firstly lectures of building production and construction management are not clearly differentiated in present curricula although the preference of educational issues is different mutually. And in case of offering both lectures, it is possible to open a lecture of building production as a primary subjects in an early period of undergraduate school.

いる講義も 3 割ほど見られる。

類型 II と III は、建築生産活動を幅広く扱う講義である。両者は「建 築の利用 (視点 5 )」の講義回数で分けられており、後者の方が視点

\section{表 1 講義類型の概要 ${ }^{1)}$}

\begin{tabular}{|c|c|}
\hline $\begin{array}{l}\text { 分類 } \\
\text { 方法 }\end{array}$ & $\begin{array}{l}\text { 講義類型 I : 視点 } 4 \text { の講義 } 7 \text { 回超 } \\
\text { 譲義類型 II : 視点 } 4 \text { の講義 } 7 \text { 回以下かつ視点 } 5 \text { の講義 } 3 \text { 回未満 } \\
\text { 講義類型IIII : 視点 } 4 \text { の講義 } 7 \text { 回以下かつ視点 } 5 \text { の講義 } 3 \text { 回以上 }\end{array}$ \\
\hline 摘要 & 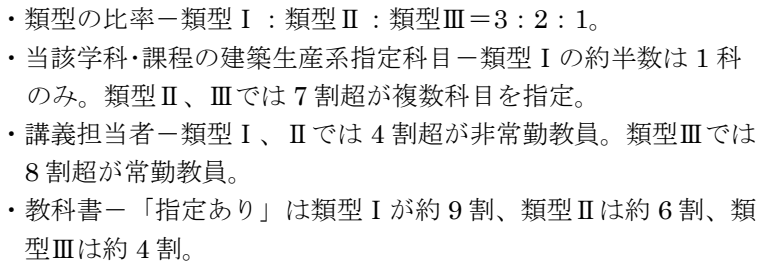 \\
\hline
\end{tabular}

講義類型 I

$\begin{array}{llllll}0 \% & 20 \% & 40 \% & 60 \% & 80 \% & 100 \%\end{array}$

視点 0 ：建築生産社会の形成(34)

視点 1 ：日本経済と建築生産(37)

視点 $2:$ 建築生産の社会的分業(37)

視点 3 : 建築プロジェクトの編成(37)

視点 4 ：工事の実施(37)

視点 5 : 建築の利用 $(37)$

視点 6 ：建築生産の国際化(37)

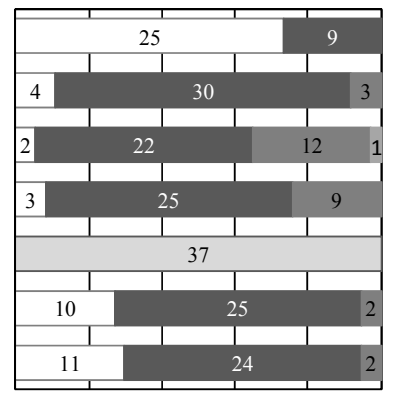

講義類型 II

$\begin{array}{llllll}0 \% & 20 \% & 40 \% & 60 \% & 80 \% & 100 \%\end{array}$

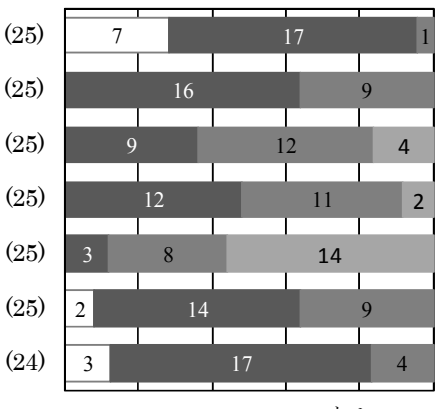

講義類型 III

$\begin{array}{llllll}0 \% & 20 \% & 40 \% & 60 \% & 80 \% & 100 \%\end{array}$

図 1 講義回数の配分の違い注 6)

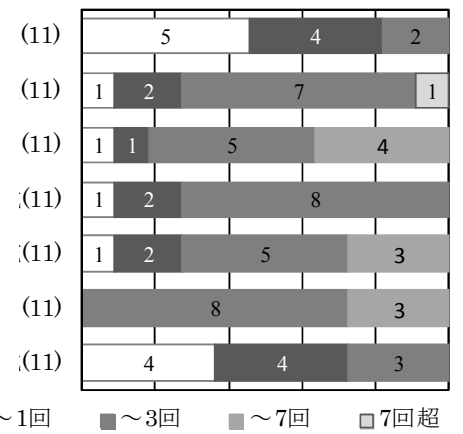

Chairman of the Board of Directors, A/E WORKS Association, Dr. Eng.

A/E WORKS 代表理事・博士（工学）

（干 171-0014 豊島区池袋 2-24-2-106)

東京工芸大学工学部建築学科 准教授・博士 (工学)

国士舘大学理工学部理工学科建築学系 准教授 - 博士 (環境学)

建築研究所 研究員 - 博士 (工学)

首都大学東京大学院都市環境科学研究科建築学域 教授・博士 (工学)
Assoc. Prof., Faculty of Engineering, Tokyo Polytechnic Univ., Dr. Eng. Assoc. Prof., School of Science and Engineering, Kokushikan Univ., Dr. Env.

Researcher, Building Research Institute, Dr. Eng.

Prof., Graduate School, Tokyo Metropolitan Univ., Dr. Eng. 
5 により多くの時間を充てる類型である。視点 4 の講義回数を比較す ると、類型 II の約 6 割が 5 回前後（「(3 回超) 〜 7回」）を割いている のに対し、類型IIIの約 7 割が 3 回以下に止まっている。類型IIIでは、 こうして生まれた時間的余裕が視点 1 から 3 に分配され、講義の時間 配分が最も平準化されている。

なお講義回数の合計が 10 回未満になる回答が 12 件見られ、その 11 件が類型 II に含まれている。つまり類型 I と IIIには、こうした回答は ほとんど含まれておらず、講義回数の合計の内訳にも大きな違いは見 られなかった注7)。

\section{3. 教育項目ごとの教示の程度の違い}

\section{(1) 視点 Oに含まれる教育項目}

建築生産関連科目では、今日の建築生産の背景として建築生産史を 講義することがある。取り上げる時代は近世後期以降に絞られており、 「一部分なら教えている」を含めても、教育項目 0-1（古代から中世） を教えている講義は 1 割に満たない(図 $2(1)) 。$

教育項目 0-1に比べると、0-2（近世から近代）を取り上げる講義は 多い。明治以降に限定寸れば注 8 、 、類型 II やIII $の ~ 4$ 割前後の講義が教育 項目 0-2 を少なくとも「一部分なら教えている」。

\section{（2）視点 1 から視点 3 に含まれる教育項目}

国内の新築活動は視点 1 から 3 の三つの階層から捉えられる 注9)。基 本的に「建築生産」の講義と「建築施工」の講義の違いは、これらに 関する教示の違いと考えて良い。つまり、教育項目 1-1（建築生産の 経済規模）、1-2（建築生産を担う職種）、2-4（建築生産を支える法規・ 規格・約款)、3-1 (設計と施工の分節と統合) を「教えている」講義 は、類型 I は 3 割前後に止まるが注 ${ }^{10)}$ 、類型 II では 6 割を超えており、 類型IIIでも半数ほどを占める（図 2 (2))。

また類型 I と比べると類型 II やIII の方が、住宅分野の教育項目を重 視する傾向も見られる。教育項目 1-3（日本の住宅生産の特徴）、2-2 (戦後の住宅大量生産のインパクト)、2-3（住宅生産の転換）、3-2（住 宅生産の様々な分業と統合）の四つは、専ら住宅分野に関寸る内容で ある。類型 I の $3 / 4$ 前後はこうした教育項目を「教えていない」が、 類型而の $3 / 4$ 前後と類型 II のほぼ半数は少なくとも「一部分なら教 えている」。

\section{（3）視点 4 に含まれる教育項目}

視点 4 には建築工事の実務的内容が対応する。類型 I はこうした内 容に 7 回超の講義を充てる類型である（表 1 ）。「一部分なら教えてい る」を含めれば、どの教育項目も 9 割前後が取り上げられている。特 に教育項目 4-4 (各種工事) は「教えている」が 8 割を超えており、

この類型の教育内容の中核であることが分かる（図 2 (3))。

一方、類型 II と III は視点 4 の講義を 7 回以下に止めている類型であ る。そのため類型 II では工事の実務的内容を管理分野に絞る傾向があ る。つまりこの類型の $1 / 4$ 前後は教育項目 4-4 や 4-3（工事準備）を 「教えていない」が、教育項目 4-2（工事管理）の教示の程度は類型 I とほとんど変わらず、むしろ 4-1（コスト管理）を「教えている」 講義は類型 II の方が多い。

類型而は視点 5 に 3 回以上の講義を割く類型である。教育項目 4-3 や 4-4 といった工事の実務的内容を「教えていない」講義が半数を超 える。但し工事管理分野まで省略してしまうことは少ない。「一部分 なら教えている」を含めれば、約 7 割が教育項目 $4-2$ を教えており、
4-1 も約 6 割が教えている。

\section{(4) 視点 5 に含まれる教育項目}

視点 5 には既存建物の利用や改修が対応する。従来、これらは建築 生産の周辺的業務と見なされてきたが、産業構造の転換によって重要 性が増すと予想される分野である。「一部分なら教えている」を含め れば、類型而の半数程度が視点 5 の全ての教育項目を教えている（図 2 (4))。なお類型IIIでも視点 5 の講義時間の平均は 3.7 回である。従 来科目の中で建築の利用・再生分野の講義を行う場合、配分できる時 間はこの程度が限度と考えられる。

類型 II の約 9 割が視点 5 の講義時間を確保している（図 1 ）。しか しその平均は 1.1 回に過ぎず、教育項目 5-3（建築利用とマネジメン ト）と 5-5（利用の構想力）を「教えていない」講義が約 7 割を占め

る。実質的には改修工法の解説などに止まっていると考えられる。

一方、類型 $\mathrm{I}$ は視点 5 を基本的に教えていない。つまりこの類型の 約 3 割は視点 5 の講義時間を確保しておらず、1 回に満たない講義を 含めれば約 $2 / 3$ を占める注 11 。 残りの $1 / 3$ ほどは教育項目 5-1（建 築の利用と再生）や $5-2$ （建築を利用寸る様々な視点）を「一部分な ら教えている」程度である。

\section{(5) 視点 6 に含まれる教育項目}

視点 6 は建築生産のグローバリゼーションに対応する。この分野を 最も積極的に扱っているのは類型 II である。その 7 割が教育項目 6-1 (ゼネコン関連）を少なくとも「一部分なら教えている」(図 2 (5))。 6-4（規格や資格の相互認証）でもそうした講義が半数ほどを占めてお り、設問で見ると 6-4e）（品質管理のグローバル化）を「教えている」 講義が 6 割に達する。つまりこの類型では大手ゼネコンの動向を中心 に視点 6 の講義を行っている。

類型而の約 4 割が視点 6 の講義時間を確保していない（図 1 )。そ の一方で教育項目 6-1、6-3、6-4 の全てについて少なくとも「一部分 なら教えている」講義が 3 割ほど存在する。

類型 I では 8 割前後が教育項目 6-4 以外を「教えていない」。設問 6-4e)を少なくとも「一部分なら教えている」講義が $2 / 3$ を超えるこ とから、この分野を取り上げる場合には ISO9000 シリーズなどを解 説していると考えられる。

\section{4. 教育項目の選択傾向の整理}

\section{（1）整理方法}

本報では、教示の程度の集計に基づき、講義で取り上げる視点や教 育項目の傾向を 5 種類に整理した注 ${ }^{12)}$ 。具体的には「必須項目」「準必 須項目」「一部を選択」「担当者による」「類型によっては不要」の五 つに分類した（表 2 の例）。但し「必須項目」に分類された教育項 目は講義類型 I に一つ現れただけであり、教育項目の選択傾向は実質 的に 4 種類に整理された。

\section{（2）講義類型と準必須項目}

講義に含まれる「準必須項目」が最も多いのは講義類型 II であり、 最も少ないのは講義類型 I である。教育項目ごとに見た場合、類型 II の「準必須項目」が 10 項目になるのに対し、類型 I は「必須項目」 を含めても 4 項目に止まる。類型而は両者の中間の 8 項目になる（表 2)。

「準必須項目」に着目すれば、講義類型 I と II は視点 4 （工事の実 施）の教育項目で類似しており、講義類型 II とIIIは視点 1 （日本経済 


\begin{tabular}{|l|l|l|l|}
\hline 1 & \multicolumn{2}{|c|}{1} \\
\hline 1 & \multicolumn{2}{|c|}{10} \\
\hline & 4 & \multicolumn{2}{|c|}{7} \\
\hline & \multicolumn{2}{|c|}{7} \\
\hline
\end{tabular}

（1）視点 0

講義類型 I

$\begin{array}{llllll}0 \% & 20 \% & 40 \% & 60 \% & 80 \% & 100 \%\end{array}$

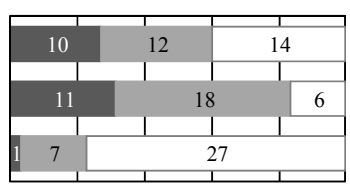

2 -1建築工事の機械化・工業化、情報化 $\left(35^{*}\right)$

2-2戦後の住宅大量建設のインパクト $\left(35^{*}\right)$

2-3住宅生产の転換 $\left(33^{*}\right)$

2-4建築生産を支える法規・規格・約款 $\left(34^{*}\right)$

$2-5$ 建築生産の重層性 $\left(35^{*}\right)$

$3-1$ 設計と施工の分節と統合 $\left(34^{*}\right)$ 3-2住宅生産の様々な分業と統合 $\left(34^{*}\right)$

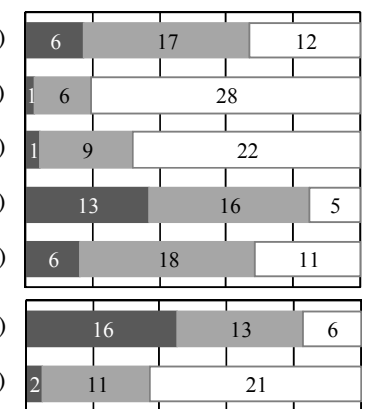

講義類型 II

$\begin{array}{llllll}0 \% & 20 \% & 40 \% & 60 \% & 80 \% & 100 \%\end{array}$

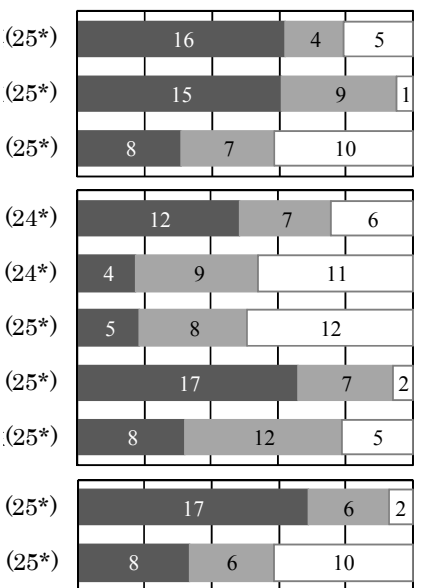

講義類型 III

$\begin{array}{llllll}0 \% & 20 \% & 40 \% & 60 \% & 80 \% & 100 \%\end{array}$ $:\left(11^{*}\right)$

$\left(11^{*}\right)$

$\left(11^{*}\right.$

$\left(11^{*}\right)$

$\left(11^{*}\right)$

$\left(11^{*}\right)$

$\left(10^{*}\right)$

$\left(11^{*}\right.$

$\left(11^{*}\right)$

$\left(11^{*}\right)$

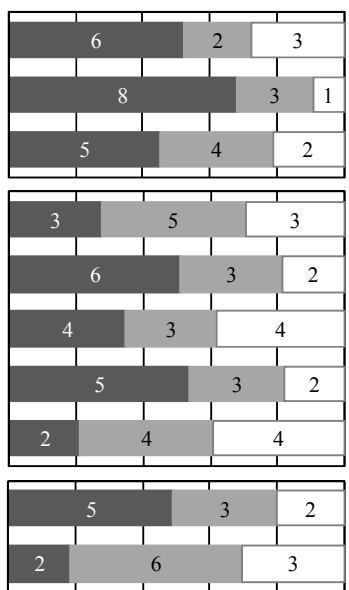

(2) 視点 1 から 3

講義類型 I

$\begin{array}{llllll}0 \% & 20 \% & 40 \% & 60 \% & 80 \% & 100 \%\end{array}$

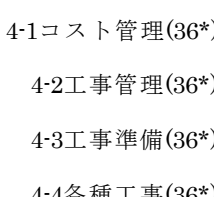

4-4各種工事( $\left(36^{*}\right)$

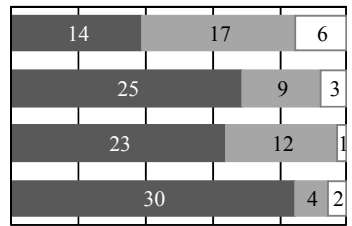

講義類型 II

$\begin{array}{llllll}0 \% & 20 \% & 40 \% & 60 \% & 80 \% & 100 \%\end{array}$ $\left(25^{*}\right)$

$\left(25^{*}\right)$

$\left(25^{*}\right)$

$\left(25^{*}\right)$

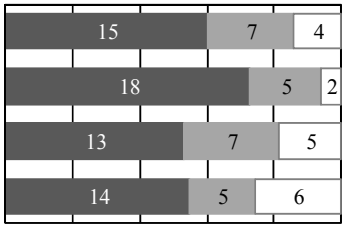

講義類型 III

$\begin{array}{llllll}0 \% & 20 \% & 40 \% & 60 \% & 80 \% & 100 \%\end{array}$ $\left(11^{*}\right)$ $\left(11^{*}\right)$

(11*) $\left(11^{*}\right)$

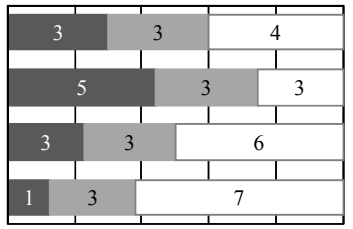

（3）視点 4

講義類型 I

$\begin{array}{llllll}0 \% & 20 \% & 40 \% & 60 \% & 80 \% & 100 \%\end{array}$

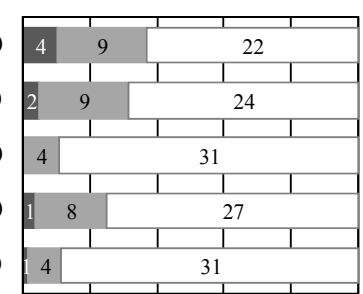

講義類型 II

$\begin{array}{llllll}0 \% & 20 \% & 40 \% & 60 \% & 80 \% & 100 \%\end{array}$

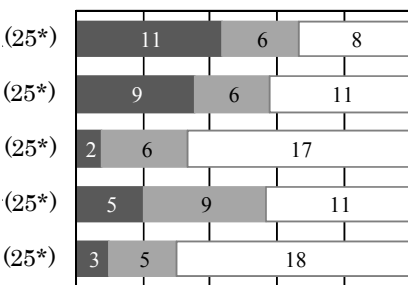

講義類型 III

$\begin{array}{llllll}0 \% & 20 \% & 40 \% & 60 \% & 80 \% & 100 \%\end{array}$

$\left(11^{*}\right)$

$\left(11^{*}\right)$

$\left(11^{*}\right)$

(11*)

$\left(11^{*}\right)$

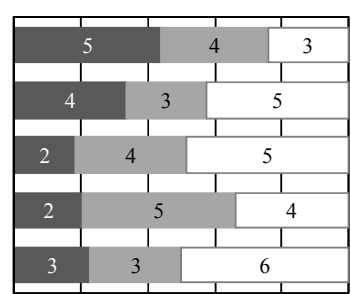

(4) 視点 5

講義類型 I

$\begin{array}{llllll}0 \% & 20 \% & 40 \% & 60 \% & 80 \% & 100 \%\end{array}$

6-1ゼネコン関連 $\left(35^{*}\right)$

6-2住宅メーカー関連 $\left(35^{*}\right)$

6-3建材関連 $\left(36^{*}\right)$

6-4規格や資格の相互認証 $\left(35^{*}\right)$
講義類型 II

$\begin{array}{llllll}0 \% & 20 \% & 40 \% & 60 \% & 80 \% & 100 \%\end{array}$

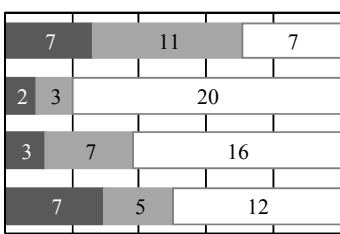

講義類型 III $\begin{array}{llllll}0 \% & 20 \% & 40 \% & 60 \% & 80 \% & 100 \%\end{array}$

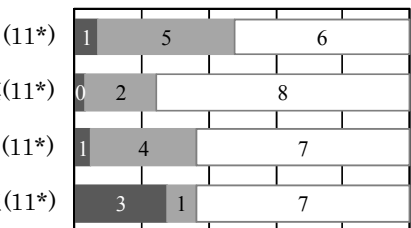

(5) 視点 6 
と建築生産）の教育項目で類似する。講義類型 I と IIII直接的な類似 性は見られないが、三つの講義類型を通して見るとそれぞれ視点 3 (建築プロジェクトの編成) を介して緩やかに関連性を持っていると 考えられる。

\section{（3）講義類型と選択的な教育項目}

どの講義類型も 25 の教育項目の半分ほどを「一部を選択」と「担 当者による」が占める。それぞれの内訳は類型 I では 6 項目ずつ、類 型 II では 2 項目と 11 項目、類型IIIでは 6 項目と 10 項目である。こう した選択的な教育項目の多さが、建築生産関連科目の大きな特徽と考 えられる。

なお「類型によっては不要」な教育内容は、類型 II では 2 項目、類 型III では 1 項目しか現れない。一方、類型 I では 25 の教育項目の中 の 9 項目が「類型によっては不要」と分類された。

\section{5. 建築生産関連科目の講義のあり方に関する考察}

講義の中で取り上げられる教育項目に着目すると、建築生産関連科 目の三つの講義類型の講義方針は表 3 の通りになる。表 1 に示した講 義状況も加味すれば、建築生産関連科目の現状について次の 3 点を指 摘できる。

大学等の科目として「建築生産」と「建築施工」は、どちらも建築 生産に関する指定科目として扱われているが注 ${ }^{13)}$ 、明らかに異なる方 向性を持つ。つまり「企画、設計、工事施工等の建築物が生産される 過程」注 ${ }^{14)}$ のうち、専ら工事施工段階を扱うのが後者である。一方、 前者は工事施工段階に重点を置きつつも、建物が生産される一連の過 程を取り上げようとする科目である。

但し現状のカリキュラムでは「建築生産」と「建築施工」の科目は 未分化の状態にある。一般に科目名は大学等の学則で定められている ことから注 ${ }^{15)}$ 、変更は必ずしも容易ではない。そのため前報に示した ように注 16 、講義類型 II やIII $1 / 4$ が科目「建築施工」の中で行われ、 類型 I の約 3 割も「建築生産」で行われている。

「建築生産」にせよ「建築施工」にせよ、現在の建築生産関連科目 は主に学部 3 年生に対して開講されている注 17)。しかしこうした開講 時期は再考の余地がある。確かに「建築施工」は実務的な科目である ため、学部後半の開講が望ましいと考えられる。一方、視点 4 を除け ば、「建築生産」の講義内容は建築的な専門知識がなくとも理解可能 である。従って、例えば「建築生産」と「建築施工」の両方を持つ力 リキュラムなどでは、前者を学部前半の基礎科目に位置づけることも 可能と考えられる。

\section{6. まとめ}

以上、建築生産関連科目で取り上げられている教育項目を三つの講 義類型ごとに整理した。これらを参考にすることで、講義計画や教材 作成が円滑化すると考えられる。またこの整理を通して、建築生産に 関する講義（類型 II ・III） と建築施工に関寸る講義（類型 I ）の教育 項目の違いも明らかになった。前者のうち、建築の利用・再生分野に 比較的多くの時間を充てる類型而は、新たな講義構成と考えられる。 今回の調査では「建築再生」といった科目名称は確認されなかったが、 今後の産業的な広がり方によってはそうした新科目の開講も必要に なると考えられる。

なお講義計画等に本報の整理を活か寸場合、「必須項目」や「準必
表 2 教育項目の選択傾向の整理注 16)

\begin{tabular}{|c|c|c|c|c|c|c|c|}
\hline \multicolumn{2}{|r|}{ 教育内容 } & \multicolumn{2}{|c|}{$\begin{array}{c}\text { 講義類型 } \\
\text { I }\end{array}$} & \multicolumn{2}{|c|}{$\begin{array}{c}\text { 講義類型 } \\
\text { II } \\
\end{array}$} & \multicolumn{2}{|c|}{$\begin{array}{c}\text { 講義類型 } \\
\text { III }\end{array}$} \\
\hline 視点 & 教育項目 & 視点 & \begin{tabular}{|l|} 
教育 \\
項目 \\
\end{tabular} & 視点 & $\begin{array}{l}\text { 教育 } \\
\text { 項目 }\end{array}$ & 視点 & \begin{tabular}{|l} 
教育 \\
項目
\end{tabular} \\
\hline \multirow{2}{*}{$\begin{array}{l}\text { 視 } \\
\text { 点 } \\
0\end{array}$} & 0-1 古代から中世の建築生産 & \multirow{2}{*}{-} & - & \multirow{2}{*}{$※$} & - & \multirow{2}{*}{$※$} & - \\
\hline & 0-2 近世から近代の建築生産 & & - & & $※$ & & $※$ \\
\hline \multirow{3}{*}{$\begin{array}{c}\text { 視 } \\
\text { 点 } \\
1\end{array}$} & 1-1 建築生産の経済規模 & \multirow{3}{*}{$※$} & $\triangle$ & \multirow{3}{*}{ O } & $\bigcirc$ & \multirow{3}{*}{$\bigcirc$} & $\bigcirc$ \\
\hline & 1-2 建築生産を担う業種 & & $\triangle$ & & $\bigcirc$ & & $\bigcirc$ \\
\hline & 1-3 日本の住宅生産の特徵 & & - & & $※$ & & $\bigcirc$ \\
\hline \multirow{5}{*}{$\begin{array}{l}\text { 視 } \\
\text { 点 } \\
2\end{array}$} & $2-1$ 建築工事の機械化 · 工業化、情報化 & \multirow{5}{*}{$※$} & $\triangle$ & \multirow{5}{*}{$\triangle$} & $\bigcirc$ & \multirow{5}{*}{$\triangle$} & $\triangle$ \\
\hline & 2-2 戦後の住宅大量建設のインパクト & & - & & $※$ & & $\bigcirc$ \\
\hline & 2-3 住宅生産の転換 & & $※$ & & $※$ & & $\triangle$ \\
\hline & 2-4 建築生産を支える法規・規格・約款 & & $\triangle$ & & $\bigcirc$ & & $\bigcirc$ \\
\hline & 2-5 建築生産の重層性 & & $\triangle$ & & $\triangle$ & & $\triangle$ \\
\hline \multirow{2}{*}{$\begin{array}{c}\text { 視 } \\
\text { 点 } \\
3\end{array}$} & 3-1 設計と施工の分節と統合 & \multirow{2}{*}{$\triangle$} & $\bigcirc$ & \multirow{2}{*}{$\bigcirc$} & $\bigcirc$ & \multirow{2}{*}{$\triangle$} & 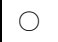 \\
\hline & 3-2 住宅生産の様々な分業と統合 & & $※$ & & $※$ & & $\triangle$ \\
\hline \multirow{4}{*}{$\begin{array}{l}\text { 視 } \\
\text { 点 } \\
4\end{array}$} & 4-1 コスト管理 & \multirow{4}{*}{$\bigcirc$} & $\triangle$ & \multirow{4}{*}{0} & $\bigcirc$ & \multirow{4}{*}{$※$} & $\triangle$ \\
\hline & 4-2 工事管理 & & $\bigcirc$ & & O & & 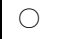 \\
\hline & 4-3 工事準備 & & $\bigcirc$ & & $\bigcirc$ & & $※$ \\
\hline & 4-4 各種工事 & & (C) & & $\bigcirc$ & & $※$ \\
\hline \multirow{5}{*}{$\begin{array}{l}\text { 視 } \\
\text { 点 } \\
5\end{array}$} & 5-1 建築の利用と再生 & \multirow{5}{*}{$※$} & $※$ & \multirow{5}{*}{$※$} & $\bigcirc$ & \multirow{5}{*}{$\triangle$} & $\bigcirc$ \\
\hline & 5-2 建築を評価寸る様々な視点 & & $※$ & & $※$ & & $※$ \\
\hline & 5-3 建築利用とマネジメント & & - & & $※$ & & $※$ \\
\hline & 5-4 診断から修繥、改修まで & & - & & $※$ & & $\triangle$ \\
\hline & 5-5 利用の構想力 & & - & & $※$ & & $※$ \\
\hline \multirow{4}{*}{$\begin{array}{l}\text { 視 } \\
\text { 点 } \\
6\end{array}$} & 6-1 ゼネコン関連 & \multirow{4}{*}{$※$} & $※$ & \multirow{4}{*}{$※$} & $\triangle$ & & $※$ \\
\hline & 6-2 住宅メーカー関連 & & - & & - & & $※$ \\
\hline & 6-3 建材関連 & & - & & $※$ & & $※$ \\
\hline & 6-4 規格や資格の相互認証 & & $※$ & & $※$ & & $※$ \\
\hline 凡例 & $\begin{array}{ll}\text { : @ 必須項目 } & \text { :「教えている」 } \\
\bigcirc \text { 準必須項目 } & \text { : 「教えている」 } \\
\triangle \text { 一部を選択 } & \text { :「教えている」 } \\
\text { ※ 担当者による } & \text { : 「教えていない」 } \\
- \text { 類型によっては不要 : 「教えていない」 }\end{array}$ & $\begin{array}{l}75 \% \\
40 \% \\
\text { 「教 } \\
\text { が } 4 \\
\text { が } 7\end{array}$ & $\begin{array}{l}\text { \%超 } \\
\text { \%超 } 7 \\
\text { えて } \\
0 \% \text { 超 } \\
5 \% \text { 超 }\end{array}$ & $\begin{array}{l}5 \% \text { 以 } \\
\text { 小ない } \\
75 \%\end{array}$ & $\begin{array}{l}\text { 以下 } \\
\text { 专 } \\
\text { o以下 }\end{array}$ & $40 \%$ & 6以下 \\
\hline
\end{tabular}

表 3 教育項目の取り上げ方から見た講義方針の違い

\begin{tabular}{|c|c|}
\hline 種類 & 講義方針 \\
\hline 講義類型 I & $\begin{array}{l}\text { 建築施工に関寸る講義として、視点 } 4 \text { の各種工事が中 } \\
\text { 心になる。但し建築生産の経済規模や業種までは取り } \\
\text { 上げることも少なくない。 }\end{array}$ \\
\hline 講義類型 II & $\begin{array}{l}\text { 建築生産に関する講義として、建設活動と社会との関 } \\
\text { 係を幅広く取り上げる。視点 } 4 \text { は工事管理分野に重点 } \\
\text { を置く傾向がある。 }\end{array}$ \\
\hline 講義類型 IIII & $\begin{array}{l}\text { 建物の利用・再生を含む講義。住宅分野に重点を置く } \\
\text { こともある。視点 } 4 \text { の各種工事は取り上げないことも } \\
\text { 少なくない。 }\end{array}$ \\
\hline
\end{tabular}

須項目」のみが重要なわけではない。「一部を選択」や「担当者によ る」といった選択的な教育項目の扱い方が、講義の様々なバリエーシ ヨンを生み出寸ためである。実際、大学等の講義内容に規範が求めら 
れるとしても、学科・課程のカリキュラムには一定の幅が存在する。 また講義担当者の創意工夫は、選択的な教育項目への多様な対応とな って現れる。つまり教育の実践上は選択的な教育項目への対応が重要 になる。次報ではこうした教育項目に関する対応状況を分析すること によって、建築生産関連科目の講義計画や教材作成の要点を明らかに する。

\section{〈謝辞〉}

本調査研究を実施するにあたり、財団法人建築技術教育普及センタ 一の平成 24 年度調查・研究助成を受けた。また建築生産教育に関す るアンケート調查では全国の大学等の担当教員の方々から回答を頂 いた。ここに記して感謝の意を表します。

\section{参考文献}

1）佐藤考一・角田誠・森田芳朗・朝吹香菜子・角倉英明，“建築生産関連科目の 教育項目と講義類型の整理一高専及び大学の建築生産教育に関する調査研 究”, 日本建築学会技術報告集第 44 号, pp.387-391, 2014.2.

2）佐藤考一・角田誠・森田芳朗・朝吹香菜子・角倉英明, 工業高等専門学校お よび大学の建築生産教育に関する調査研究報告書, (財)建築技術教育普及セン ター平成 24 年調査・研究助成，建築環境ワークス協同組合，2013.3.

3）建築技術教育普及センター, “一級建築士試験 指定科目の確認結果”, 建築 技術教育普及センター（http://www.jaeic.or.jp/kamoku-1k_kekka.htm)，(閲 覧 2012 年 6 月 30 日).

\section{注}

注1）建築生産関連科目の教育項目を整理するに当たって、まず建築生産の捉え 方を七つの視点に整理した。これは「建築生産システム(新建築学体系 44)」 に示された建築生産の概念モデルを拡張したものである。具体的には、国 内の新築活動を捉える四つのレベル分け（視点 1 から 4) に対して、既存 建物の利用や改修を捉える視点（視点 5 「建築の利用」）を加え、次いで 建設業のグローバリゼーションを捉える視点（視点 6 「建築生産の国際 化」）と建築生産活動の歴史的背景を捉える視点（視点０「建築生産社会 の形成」）を追加した ${ }^{1}$ 。

25 の教育項目（内訳 93 項目）は、以上の七つの視点に基づいて、建築生 産関連科目の代表的な教科書類 9 冊の内容を整理した結果である(前報「 3 建築生産関連科目の教育項目の整理」参照） 1)。つまり現在の建築生産関 連科目で講義しうる内容の一覧を示している。

なお、前報の表 2 の中の「1-3.建築生産を担う業種」は誤記であり、「1-3 日本の住宅生産の特徴」が正しい。ここに記して訂正する。

注2）一級建築士受験が可能なカリキュラムを持つ大学等 242 学科・課程を対象 とし、93 件の回答を得た。アンケート回答の概要は前報の表 3 参照 ${ }^{1)}$ 。な お本研究では「大学、工業高等専門学校、職業能力開発大学校、短期大学】 を「大学等」と呼んでいる。

注3）今回の調查では「講義時間 90 分を 1 回」として、七つの視点ごとに講義 時間の回答を求めた。但し現場見学や演習などに充てられている時間は碓 認していない。なお、現在の半期講義は 15 回の構成が一般的と考えられ るが、講義時間の合計を見ると約 7 割が 14 回以上であった（当該設問の 有効回答 73 件)。

注4）各教育項目の教示の程度は「教えている」、「一部なら教えている」、「教え ていない」の3段階に分けて確認した。

注5）アンケート回答は原則として「科目「建築生産」(「生産工学」「建築生産管 理」などを含む）を担当されている方」に依頼し、「科目「建築生産」を開講 されていない場合、これに近いと思われる科目（「建築施工」など）の担当 者」にも回答を求めた。そのため有効回答 73 件のうち 33 件は「建築施工」 等の科目について回答している。前報の図 $5(2)$ 参照 ${ }^{1}$ 。

注6）講義類型 I $の$ 視点 4 への講義回数の配分は全て $「 7$ 回超」となったが、こ の中には 15 回超が 1 件含まれる
注7）講義回数 ${ }^{\text {注 } 39}$ の合計は、類型 I と III の両方とも 14 回以上が 8 割を超えてい る。一方、類型IIでは 14 回未満が 6 割を超えており、その 7 割ほどを 10 回未満が占めている。

注8）設問（教育項目の内訳） 0-2c）（明治初期）と 0-2d）（明治中期 ） の回答 による。なお教育項目の内訳は前報の表 2 参照 ${ }^{1}$ 。

注9）前報の図 1 参照 1)。

注10)設問ごとに見ると、類型 I の 7 割前後が 2-4d）(契約）や 3-1a）(設計と施 工のプロセス）を「教えている」。なお建築生産に関する指定科目を一つ しか持たない学科・課程では、「建築施工」の講義に工事施工以外の内容 が付加されることも考えられる。しかし今回のアンケート調查結果からは そうした傾向を確認できなかった。

注11) 類型 $\mathrm{I}$ では視点 5 の講義回数「(0 回超) 1 回」が 25 件ある（図 1 )。こ のうち講義回数 1 回が 10 件を占める。

注12)次の考え方に従って整理した: (1)教示の程度に関する集計を $12.5 \%$ 刻みで 八つに区分する。但し $37.5 \% （ 62.5 \%)$ の闎值は $40 \% （ 60 \% ）$ の概数に 丸める。(2)「教えている」割合が 7 8 区分を占める場合は「必須項目」、 4〜6 区分を占める場合は「準必須項目」とする。(3)「教えていない」割 合が 7〜8 区分を占める場合は「類型によっては不要」、4〜6 区分を占め る場合は「担当者による」とする。(4)上記の(2)にも(3)にも該当しない場合 （「教えている」割合と「教えていない」割合の両方が 3 区分以下）は「一 部を選択」とする。

注13)名称に「生産」を含む科目を「建築生産」等、「施工」を含む科目を「建 築施工」等と呼ぶとすれば2)、調查対象とした 242 学科・課程のうち、建 築生産指定科目に「建築生産」等を持つものは 115 件、科目名「建築施工」 等を含むものが 170 件、両者を含むものが 53 件であった（どちらも含ま ないものは 10 件） ${ }^{3)}$ 。なおアンケートの回答科目の名称の内訳は前報の図 5 参照 ${ }^{11}$ 。

注14）指定科目「建築生産」に関する講義の標淮的内容（平成 20 年国土交通省 告示第 740 号)。

注15)大学は、学科ごとに「教育研究上の目的を学則等に定め」(大学設置基準 第 2 条)、「必要な授業科目を自ら開設し、体系的に教育課程を編成する」 (同第 19 条)。そのため学則には「教育課程及び授業日時数に関する事項」 を記載しなければならない (学校教育施行規則第 4 条)。

注16) 前報の図 5 参照 ${ }^{1}$ 。

注17) 前報の表 3 参照 ${ }^{11}$ 。

[2013 年 10 月 3 日原稿受理 2014 年 1 月 24 日採用決定 $]$ 